\title{
LATIN AMERIKA'DA COVID-19 PANDEMISININ SOSYOEKONOMIK ETKILERI: BREZILYA VE MEKSIKA ÖRNEKLERI
}

\author{
Socioeconomic Impacts of Covid-19 Pandemic in Latin America: \\ Cases of Brazil and Mexico
}

\section{Anahtar \\ Kelimeler: \\ Covid-19, \\ Brezilya, \\ Meksika}

JEL Kodları:

O54, N36, N46

Keywords:

Covid-19,

Brazil,

Mexico

JEL Codes:

O54, N36, N46
Ceren UYSAL OĞUZ* \& E. Nur SEZEK*
Aralık 2019'da ortaya çıkan Covid-19 pandemisi hızlı bir şekilde tüm dünyayı etkisi altına almıştır. Virüs Latin Amerika'da ilk kez Şubat 2020 sonlarında görülmüş, ilk vakanın Brezilya'da bildirilmesinin ardından Covid-19 bölgenin diğer ülkelerine de sıçramıştır. Latin Amerika'da vakaların hızlı bir şekilde artması, bölgeyi Mayıs 2020 sonunda pandeminin o dönemdeki merkezi haline getirmiştir. Pandemi bölgede çok ciddi etkiler yaratırken, birçok Latin Amerika ülkesi virüsle mücadele etmekte yetersiz kalmış, Brezilya Devlet Başkanı Bolsonaro örneğinde görüldüğü üzere pandemiyi umursamayan liderler olmuştur. Bölge ülkelerinde görülen yüksek vaka sayıları ve ölüm oranlarının yanı sıra ekonomik, toplumsal ve siyasi etkiler nedeniyle Latin Amerika Covid-19'dan en fazla zarar gören bölgelerden biri olmuştur. Bu çalışmada, 15 Eylül 2020 tarihi itibariyle bölgede en fazla vaka ve ölüm sayısına sahip Brezilya'da ve en yüksek ölüm oranına sahip olan Meksika'da pandeminin etkileri araştırılmıştır. Brezilya'daki popülist sağ Bolsonaro hükümeti ve Meksika'daki popülist sol López Obrador hükümeti, siyasi yelpazenin farklı noktalarında yer almalarına karşın, Covid-19'u önemsiz göstermeyi amaçlayan benzer söylemleri kullanmışlar ve halk sağlığını koruma konusunda başarısız politikalar izlemişlerdir. Çalışmada kullanılan veriler değerlendirildiğinde, Latin Amerika'nın iki büyük ekonomisi olan Brezilya ve Meksika'nın pandemi ile mücadelede zorlandıkları ve bu süreçte özellikle sosyoekonomik açıdan olumsuz etkilendikleri görülmüştür.

\begin{abstract}
The Covid-19 pandemic, which emerged in December 2019, has swiftly affected the whole world. The virus appeared in Latin America at the end of February 2020 when Brazil reported the first case. The rapid increase of the cases in the region made Latin America the hotspot of the Covid-19 pandemic at the end of May 2020. The effects of the pandemic in Latin America have been very grave since the countries could not contain the surge of cases, while some leaders, like Brazilian President Bolsonaro, ignored the severity of the pandemic. The economic, social and political impacts as well as a high number of cases and death rates proved that Latin America is one of the most affected regions in the world. Hence, this study examines the effects of the pandemic in Brazil and Mexico, the former with the highest number of cases and deaths, and the latter with the highest mortality rate in the region as of September 15 , 2020. Even though they are at different ends of the political spectrum, the populist right Bolsonaro government of Brazil and the populist left López Obrador government of Mexico have used similar discourses to downplay the pandemic and carried out similar unsuccessful policies regarding public health. Consequently, the assessment of various data showed that Brazil and Mexico, as more developed economies of the region, have been experiencing difficulties in coping with the pandemic and they have been negatively affected in terms of socioeconomic conditions.
\end{abstract}

\footnotetext{
* Sorumlu Yazar, Doç. Dr. Akdeniz Üniversitesi, İktisadi ve İdari Bilimler Fakültesi, Uluslararası İlişkiler Bölümü, cuysaloguz@akdeniz.edu.tr, ORCID: 0000-0001-7342-0362

** Yüksek Lisans, Akdeniz Üniversitesi, eminenursezek@gmail.com, ORCID: 0000-0003-3399-5721
}

Makale Geliş Tarihi (Received Date): 15.10.2020 ～Makale Kabul Tarihi (Accepted Date): 17.11.2020 


\section{Giriș}

Tüm dünyada hızla yayılan ve korona virüsünün yeni versiyonu olan Covid-19 (World Health Organization [WHO], 2020a), ilk olarak Aralık 2019'da Çin'de ortaya çıkmıştır (Sauer, 2020). Kısa sürede dünyanın diğer bölgelerinde de görülmeye başlayan virüs, Latin Amerika'da ilk kez 25 Şubat 2020'de Brezilya'da tespit edilmiştir (Andrus, vd., 2020, s. 593). Covid-19, 25 Şubat'tan itibaren hem Brezilya'da hem de bölgede hızlı bir şekilde yayılmaya başlamıştır. Birçok çalışmada da belirtildiği üzere sağlık sistemi yeterince güçlü olmayan Latin Amerika ülkeleri bütün dünyada olduğu gibi Covid-19 pandemisinden yalnızca sağlık alanında değil ekonomik, siyasi ve toplumsal anlamda da etkilenmiştir (Blofield, Hoffmann ve Llanos, 2020). Latin Amerika ülkelerinde var olan sosyoekonomik sorunlar pandemi sürecinde daha da derinleşmiştir.

Latin Amerika ülkeleri tarihsel olarak sömürge döneminin yarattığ ve 19. yüzyıl başlarından itibaren kazanılan bağımsızlık mücadelelerinden sonra da büyük ölçüde süren ekonomik, siyasal ve toplumsal bölünmelerin etkisini her alanda hissetmektedir. Siyasi ve ekonomik istikrarsızlığın ve toplumsal tepkilerin çoğu zaman birbirini beslediği ve birçok ülkede askeri darbelerle demokrasinin kesintiye uğradığı bu coğrafyada, sık sık popülist yönetimler de işbaşına gelmiştir. Bu çalışmada öncelikle Latin Amerika'da Covid-19 vakalarının en çok hangi ülkelerde görüldüğü ve can kaybına yol açtı̆̆ 1 araştırılmıştır. Bu amaçla bölge ülkelerinin sağlık bakanlıkları başta olmak üzere, çeşitli kaynaklardan derlenen nicel veriler analiz edilerek, 1 Mart 2020 ile 15 Eylül 2020 tarihleri arasında Latin Amerika'da en yüksek vaka sayısına sahip olan ülkeler tespit edilmiştir. Söz konusu zaman aralığında en yüksek vaka ve ölüm sayısına sahip olduğu belirlenen Brezilya ile en yüksek ölüm oranına sahip olan Meksika'daki vaka ve ölüm sayıları grafikleştirilerek analiz edilmiş, vaka yoğunluğu her iki ülkenin haritalarına yansıtılarak pandeminin coğrafi yayılımı belirlenmiştir.

Ayrıca her iki ülkede ilk vakaların tespit edilmesinin ardından Brezilya'da Devlet Başkanı Jair Bolsonaro'nun, Meksika'da Devlet Başkanı Andrés Manuel López Obrador'un pandemiyi önemsizleştirmeye yönelik söylemleri ve tutumları değerlendirilmiştir. Buradan yola çıkarak Latin Amerika'da popülist yönetim anlayışının güncel iki örneği olan Brezilya ve Meksika'da pandeminin sosyoekonomik etkilerinin incelenmesi amaçlanmıştır. Sağ popülizmin örneği olarak Brezilya'da, sol popülizmin örneği olarak Meksika'da Covid-19 pandemisinin var olan ekonomik sorunları, toplumsal ve sınıfsal ayrımı derinleştirmiş olduğu varsayımından yol çıkılarak yapılan araştırmada Brezilya ve Meksika'nın Covid-19'a yaklaşımlarının tartışmaya açılması da amaçlanmıştır. Ayrıca, çalışmanın tamamlandığı tarihte pandeminin devam ediyor olması ve Latin Amerika genelinde olumsuz tablonun ciddiyetini koruması nedeniyle ilerleyen süreçte benzer konularda gerçekleştirilecek araştırmalara bir temel oluşturmak ve bu konuda Türkçe literatüre katkı sağlamak hedeflenmiştir. İngilizce, Türkçe ve İspanyolca kapsamlı bir literatür taramasının yapıldığı çalışmada, etik kurul izni gerekmemiş, araştırma ve yayın etiğine uyulmuştur.

\section{Latin Amerika'da Covid-19}

Şubat 2020 sonlarında Brezilya'da ilk vakanın görülmesiyle birlikte Latin Amerika ülkeleri Covid-19 pandemisinin etkilerini hızlı bir şekilde hissetmeye başlamıştır. Bazı az gelişmiş ve gelişmekte olan ülkelerle birlikte Latin Amerika ülkeleri de pandeminin başlarında 
virüsü tespit edecek testi yapmakta yetersiz kalmış ve dış desteğe ihtiyaç duymuştur (Bedford, vd., 2020, s. 1016). Fakat zamanla Latin Amerika'da uygulanan test sayısı artmış ve böylece vaka tespiti kolaylaşmıştır. Bununla birlikte, bölgenin birçok ülkesinde sağlık sisteminin yetersiz olması, virüsün hızlı bir şekilde yayılmasına neden olmuş ve ölümle sonuçlanan vaka sayısı artmıştır (Özdemir, 2020). Bölgedeki ilk ölüm 7 Mart'ta Arjantin'de gerçekleşmiştir (Horwitz, Nagovitch, Sonneland ve Zissis, 2020). İlk vakanın görüldüğü Brezilya'da ise ilk ölüm 16 Mart'ta yaşanmıştır (BBC, 2020). Genel olarak bölge ülkelerinde ilk vakalar ve ardından can kayıpları Mart 2020'de görülmüştür.

Mart ayından itibaren Latin Amerika'nın hemen her ülkesinde vakalar hızla artmaya başlamıştır. Mayıs ayının sonlarına doğru ise Dünya Sağlık Örgütü (DSÖ) tarafından yayınlanan verilere göre bölgede vaka sayısı 700.000'e ulaşırken 33.000 kişi hayatını kaybetmiştir (Dellanna, 2020). Bu durum o tarihte Latin Amerika'yı Covid-19 pandemisinin yeni merkezi haline getirmiştir (Newey, 2020). Tüm Latin Amerika ülkelerinde vaka sayısı hızla artmakla birlikte en fazla vaka Brezilya'da görülmüştür (CDE, 2020). Mayıs ayı sonunda 330.000 vakaya sahip olan Brezilya, bölgede pandeminin en şiddetli şekilde etkilediği ülke olarak kayıtlara geçmiştir.

Latin Amerika'nın büyük bölümünün karşı karşıya olduğu yoksulluk, ekonomik eşitsizlik, siyasi istikrarsızlık gibi sorunlara, çoğu ülkede sağlık sisteminin yeterince gelişmemiş olması da eklenince bölgenin, pandeminin merkez üslerinden haline gelmesi kaçınılmaz olmuştur. Her ne kadar bazı ülkelerde çok sıkı önlemler uygulamaya konsa da yönetimlerin virüsün yayılmasını engelleme konusunda başarılı olduklarını söylemek zordur (Uysal Oğuz, 2020, s. 2). Virüsün yayılmasını yavaşlatmak adına alınan kararlar ekonomik problemler doğurmuş, bu ise hem halkın yaşam koşullarını zorlaştırmış hem de sağlık sistemi için daha derin sorunlar yaratmaya başlamıştır (Özdemir, 2020).

Brezilya dışında Meksika, Kolombiya, Ekvador, Peru, Panama, Guatemala gibi ülkeler pandemiden en fazla etkilenen ülkeler arasındadır (Burki, 2020). Sadece bu ülkeler değil hemen hemen bütün Latin Amerika ülkeleri, özellikle virüsün hızla yayıldığı dönemde sağlık sistemlerinin yoğunluğu kaldıramaması nedeniyle birçok sorun yaşamıştır (Caicedo-Ochoa, Rebellón-Sánchez, Peñaloza-Rallón, Cortés-Motta ve Méndez-Fandiño, 2020, s. 317). Bu ise ülkelerin içinde bulunduğu durumu daha da zorlaştırmıştır. Özellikle sağlık personeli başta olmak üzere bireylerin koruyucu ekipmanlara erişiminin kısıtlı olması virüsün bölgede yayılmasını daha da hızlandırmıştır (Panduro-Correa, Arteaga-Livias ve Rodríguez-Morales, 2020, s. 596).

Bölgede hem vaka sayıları hem de ölüm oranları hızlı bir artış gösterirken var olan ekonomik problemler daha da derinleşmeye başlamıştır. Pandemiyi kontrol altına almak için uygulanan karantina, iş yerlerinin kapanması, ulusal ve uluslararası uçuşların kısıtlanması gibi önlemler (Uysal Oğuz, 2020, s. 2) nedeniyle birçok kişi işini kaybetmiş, bazı sektörler faaliyetlerini durdurmak zorunda kalmıştır. Bu durum bölge ülkelerinde küçük-büyük çok sayıda işletmeyi, kayıt dışı çalışan sokak satıcısından devlete bağlı büyük enerji şirketlerine kadar ekonominin neredeyse tüm aktörlerini etkilemiştir (Economic Commission for Latin America and the Caribbean [ECLAC], 2020). Bölgedeki vaka sayılarının, bu çalışmada kullanılan verilerin derlendiği 15 Eylül 2020 tarihi itibariyle hâlâ yüksek olması Covid-19'un olumsuz etkilerinin devam etmesine ve derinleşmesine yol açmaktadır. 
Bu bağlamda, bölgedeki durumun genel bir panoramasını aktarabilmek amaciyla 1 Mart 2020'den 15 Eylül 2020'ye kadar Latin Amerika'da Brezilya dışındaki sekiz ülkedeki vaka sayıları derlenerek Grafik 1'de karşılaştırmalı olarak gösterilmiştir. Vaka sayılarının Brezilya'da 4,5 milyona yaklaşarak diğer ülkelerden çok daha fazla olması nedeniyle grafikte yer verilememiştir.

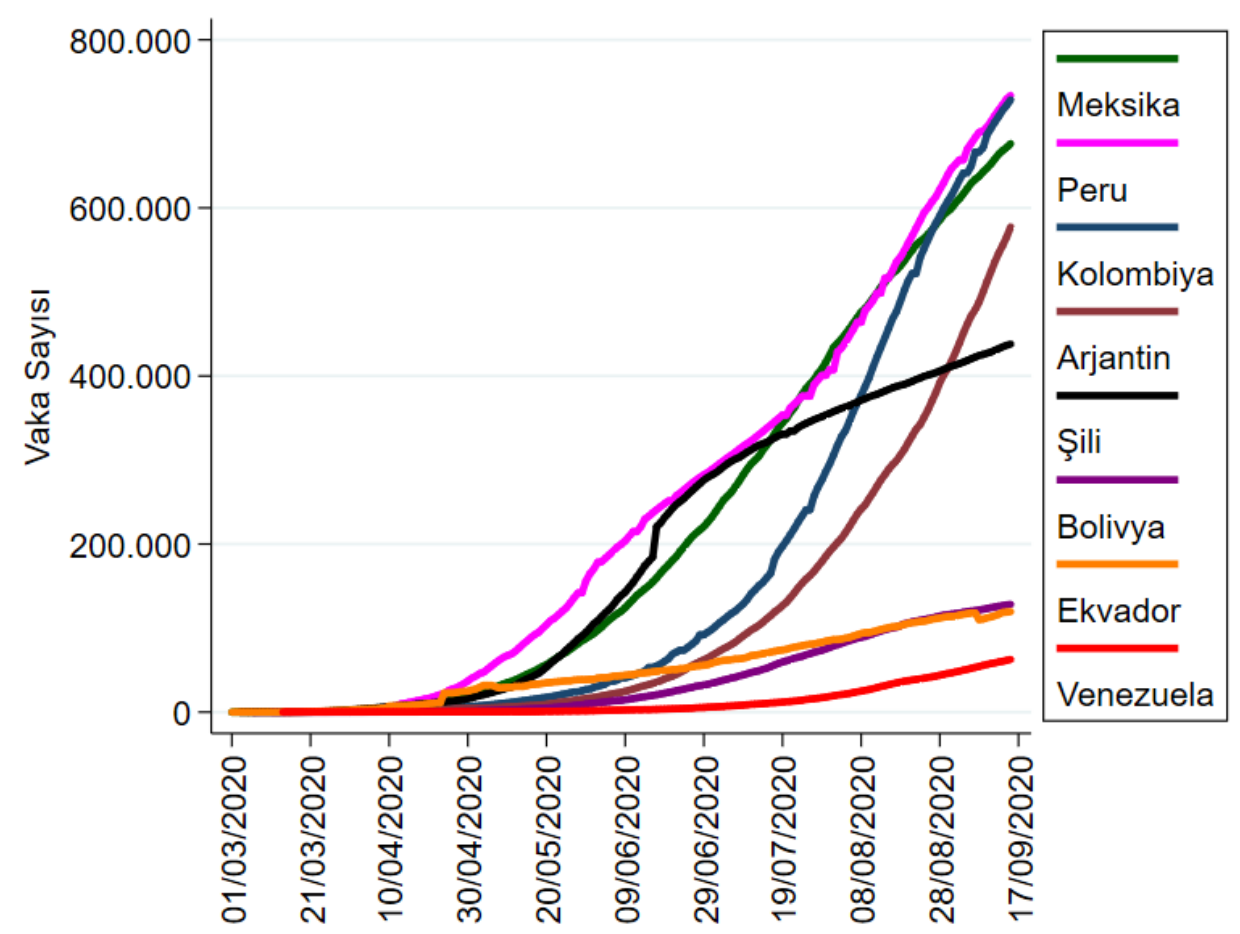

Grafik 1. Latin Amerika En Yüksek Covid-19 Vaka Sayıları (Brezilya hariç)

Kaynak: Johns Hopkins Üniversitesi verileri kullanılarak yazar tarafindan oluşturulmuştur.

Grafik 1'e göre sırayla Peru, Şili ve Meksika'da tespit edilen vaka sayıları Haziran ayında 200 bini geçerken, Kolombiya ve Arjantin'de bu eşik Temmuz ayında aşılmıştır. Peru, Kolombiya ve Meksika Ağustos ayı itibariyle 600 bin vaka sayısını geçerken, Arjantin'in bu ülkeleri takip ettiği görülmektedir. Şili'deki artış hızının ise bu dört ülkeye göre daha yavaş seyrettiğini söylemek mümkündür.

Tablo 1'de görüldüğü üzere, 15 Eylül 2020 itibariyle Brezilya'nın ardından bölgede en fazla vakaya sahip ülkeler Peru, Kolombiya ve Meksika'dır. Meksika toplam ölüm sayısında ikinci sırada yer alırken Peru ve Kolombiya'nın toplam vaka sayıları Meksika'dan yüksektir. Öte yandan Bolivya, Ekvador ve Venezuela'da tespit edilen vaka sayısı diğer bölge ülkelerine göre daha düşük olarak kayıtlara geçmiştir. Ancak toplam vaka sayısına göre Ekvador'da ölüm oranının oldukça yüksek olduğu görülmektedir. Meksika'da toplamda yaklaşık \%10 olan ölüm oranı, Ekvador'da \%9 civarındadır ve bölgenin diğer ülkelerine göre oldukça yüksektir.

$\mathrm{Bu}$ çalışma için son verilerin derlendiği 15 Eylül 2020 gününe ait resmi makamlar tarafından ilan edilen vaka sayısında ise Tablo 1'de görüldüğü gibi Brezilya ve Arjantin ön plana çıkmaktadır. 15 Eylül tarihine ait bir günlük vaka sayısında Brezilya ve Arjantin'i Kolombiya ve Meksika izlemektedir. Tablo 1'de de görüldüğü üzere, Latin Amerika bölgesinde 
15 Eylül 2020 tarihi itibariyle en yüksek vaka ve can kaybı Brezilya'da, en yüksek ölüm oranı ise Meksika'da gerçekleşmiştir. Buradan yola çıkarak her iki ülkede Covid-19'un etkilerinin incelenmesi önem kazanmaktadır.

Tablo 1. Latin Amerika'da En Yüksek Covid-19 Vaka ve Ölüm Sayısına Sahip Ülkeler (1 Mart-15 Eylül 2020)

\begin{tabular}{lccc}
\hline Ülke & $\begin{array}{c}\text { Toplam vaka sayısı } \\
\text { (15 Eylül 2020 dahil) }\end{array}$ & Ölüm sayısı & $\begin{array}{c}\text { 15 Eylül 2020'de } \\
\text { açıklanan günlük vaka } \\
\text { sayısı }\end{array}$ \\
\hline Brezilya & 4.384 .299 & 133.207 & 34.755 \\
Meksika & 676.487 & 71.678 & 4.771 \\
Peru & 744.400 & 31.051 & 1.926 \\
Kolombiya & 728.590 & 23.288 & 6.698 \\
Şili & 437.983 & 12.040 & 1.536 \\
Arjantin & 577.338 & 11.852 & 11.892 \\
Ekvador & 119.553 & 10.963 & 645 \\
Bolivya & 128.286 & 7.447 & 667 \\
Venezuela & 62.655 & 502 & 1086 \\
\hline
\end{tabular}

Kaynak: Brezilya için Worldometer, 2020; Meksika için Johns Hopkins University, 2020; Peru için Minsa, 2020; Kolombiya için Ministerio de Salud y Protección Social, 2020; Şili için Ministerio de Salud, 2020; Arjantin için Argentina Presidencia Ministerio de Salud, 2020; Ekvador için Ministerio Salud de Pública, 2020; Bolivya için Bolivia Ministerio de Salud, 2020; Venezuela için Estadísticas Venezuela, 2020’den derlenen verilerle yazar tarafindan oluşturulmuştur.

\section{Brezilya}

Brezilya, toplamda $8.515 .770 \mathrm{~km}^{2}$ yüz ölçümü ve 210 milyondan fazla nüfusu ile (Central Intelligence Agency [CIA], 2020a) Latin Amerika'nın en büyük ülkesidir. Dünyanın en büyük ilk on ekonomisi arasında yer alan (Investopedia, 2020) Brezilya'da, gelir eşitsizliği ve yoksulluk en önemli sorunlardan biridir. Örneğin, 2016 verilerine göre 1.796 milyar dolarlık GSYH ile bölgenin en büyük ekonomisi olan Brezilya'da, aynı dönemde Gini katsayıs1 0,51 olmuştur. Dolayısıyla bölgenin gelişmiş ekonomileri arasında gelir dağılımı eşitsizliğinin en yoğun yaşandığı ülke Brezilya'dır (Zanbak, 2019, s. 261, 264). Latin Amerika'nın sanayileşmiş birkaç ülkesi arasında yer alan Brezilya, aynı zamanda önemli bir tarım ve turizm ülkesidir.

\subsection{Brezilya'nın Sosyoekonomik Yapısı}

Brezilya'da dönem dönem daha da derinleşen ekonomik, siyasal ve toplumsal krizlerin tarihsel temelleri ülkenin sömürge geçmişine uzanmaktadır. Brezilya, Latin Amerika'nın geri kalan bölümünün aksine, İspanya değil Portekiz tarafından sömürgeleştirilmiştir. 19. yüzyıl başlarına kadar süren sömürge döneminden itibaren (Schwartz, 2010, s. 2) Portekiz'in en önemli şeker ve kakao tedarikçisi olmuştur (Edwards, 2008, s. 26). Böylece Brezilya hammadde tedarikçisi bir ülke haline gelmeye başlamış, bu durum ise ülkede uzun vadede ortaya çıkan ekonomik problemlerin en önemli yapı taşlarından biri olmuştur.

1822'de Portekiz'den bağımsızlığını ilan ettikten sonra bir süre daha krallıkla yönetilen Brezilya'da, özellikle varlıklı ve yoksul kesimler arasındaki sınıfsal ayrım ve beyazlarla, melezler, yerliler ve Afrika kökenliler arasındaki ırksal ayrım giderek büyümüştür (Skidmore ve Smith, 2005, s. 139). Karma bir nüfusa sahip olan Brezilya'da Afrika'dan getirilen köleler, 
hayatta kalabilen yerliler ve beyaz "elitler" arasındaki farklılıklar (Meade, 2004) toplumda var olan ayrışmaları derinleştirmiştir. Her ne kadar 1888 'de Brezilya'da kölelik kaldırılsa da (Edwards, 2008, s. 268) ülkenin toplumsal yapısında büyük değişiklikler yaşanmamış, elitler siyaset ve ekonomideki ayrıcalıklı konumlarını korumuştur. Sömürge döneminden kalma bu yapı, ülke bağımsızlığını elde ettikten sonra da varlığını sürdürmüştür. Irk ve sınıfsal ayrımın etkileri aynı şekilde günümüzde de kendini hissettirmektedir.

1889'da cumhuriyetin ilanından sonra Brezilya'da halkın farklı kesimlerini temsil eden, farklı ideolojiler benimseyen birçok siyasi parti kurulmuştur (Schwartz, 2010, s. 3). Böylece ülke sömürge ve krallık dönemlerinin ardından daha demokratik bir siyasi yapıya sahip olmuştur. Fakat bu demokratikleşme süreci ülkeyi askeri darbelerden kurtaramamıştır (Secchi, 2016, s. 90). Bu darbeler sonucunda Brezilya, farklı dönemlerde askeri diktatörlükler ile yönetilmiştir (Mahiroğulları, 2016, s. 84). Ülkede birden fazla askeri darbenin yaşanması, "demokratik" yapıyı etkilemiştir. Nihayet 1985 'ten sonra kalıcı olarak sivil demokrasiye geçilmiştir (Sakurai ve Menezes-Filho, 2011, s. 237). 1988'de kabul edilen yeni anayasa ile dört yılda bir seçimler yapılmaya başlanmıştır. 1990'lı yıllarda neoliberal ekonomi politikalarının uygulandığı Brezilya'da 2000'li yılların başında sol görüşlü hükümetler iktidara gelmiştir (Tekin, 2017, s. 97).

Brezilya'da 2002 ve 2016 yılları arasında İşçi Partisi'nden art arda ikişer kez seçilerek iktidara gelen Lula da Silva ve Dilma Rousseff' in başkanlık dönemlerinde ülkede ekonomik iyileşmeler gerçekleşmiştir (Mendonça ve Lavalle, 2019, s. 240). Ancak aynı zamanda bu dönemin yöneticileri yolsuzlukla suçlanmış (Saad-Filho ve Boffo, 2020, s. 4), Rousseff ikinci dönemini tamamlayamadan 2016 yılında başkanlıktan azledilmiş, başkan yardımcısı Brezilya Demokratik Hareketi lideri Michel Temer 2018 seçimlerine kadar başkanlığa vekalet etmiş̧tir. Lula de Silva'nın 2018 seçimlerinde tekrar aday olması gündemde iken yolsuzluk iddiaları nedeniyle tutuklanması seçimlerin gidişatını etkilemiştir (Polat, 2019, s. 599). 2018'de aşırı sağcı popülist lider Jair Bolsonaro'nun iktidara gelmesi ile Brezilya'da yeni bir dönem başlamıştır. Eski bir asker olan Bolsonaro'nun politik gündemi, kendinden önceki iki başkandan tamamen farklı bir seyir izlemiştir (Hunter ve Power, 2019, s. 68).

Seçim kampanyası sırasında askeri rejimden övgüyle bahseden Bolsonaro, demokratik olmamakla eleştirilse de seçimi kazanarak başkan olmuştur (Doğanyılmaz Duman, 2020, s. 199). Seçim kampanyasından itibaren popülist bir söylem benimseyen Bolsonaro, "Amazonların Trump' '” ya da "tropiklerin Trump'ı" şeklinde adlandırılmıştır (Rodrigues, 2019). Kadınlar, LGBTİ bireyler, yerliler, siyahiler ve solcular hakkında aşağılayıcı, saldırgan ve dışlayıcı birçok açıklama yapan (Polat, 2019, s. 600-601), tartışmalı ekonomik ve politik hamleleri ile sürekli gündemde olan Bolsonaro, Covid-19 pandemisini önemsemeyen söylemi ile de tüm dünyanın dikkatini çekmiştir.

\subsection{Brezilya'da Covid-19 Pandemisi ve Etkileri}

Latin Amerika'da en fazla vaka sayısına sahip olan Brezilya'da pandeminin başlangıcından itibaren durumun ciddiyetinin inkârı söz konusudur. Özellikle Başkan Bolsonaro'nun virüsü hafife alması ve gerekli önlemleri aktif olarak uygulamaktan kaçınması ülkenin bu durumunda etkili olmuştur (Skynews, 2020). Devlet başkanının pandemiyi ciddiye almayarak gereken önlemleri uygulamaması halkın da pandemi konusunda daha rahat hareket 
etmesine yol açmıştır. Bu ise özellikle pandemi ile mücadelenin ön saflarında yer alan sağlık çalışanlarını daha zor durumda bırakmış, vaka sayıları baş edilemeyecek bir hızda yükselmiştir (Lotta, Wenham, Nunes ve Pimenta, 2020).

Brezilya'da ilk vaka 25 Şubat 2020'de São Paulo'da tespit edilmiştir. Böylelikle Brezilya Latin Amerika'da vaka rapor eden ilk ülke olmuştur (Burki, 2020, s. 547). Sonraki süreçte Brezilya vaka sayılarının hızla artı̧̧ gösterdiği ülkelerden biri olmuştur. Bu olumsuz gelişmede, Bolsonaro'nun virüsü ciddiye almaması, basit bir grip olarak nitelendirmesi, maske kullanımı konusunda halka olumsuz örnek olması, sosyal mesafe kurallarına uymaması da etkili olmuştur (Blofield, vd., 2020). Brezilya'nın kalabalık nüfusunun ve alınmayan önlemlerin de etkisiyle kısa sürede Latin Amerika'da rapor edilen vakaların yarısından fazlası Brezilya'da gerçekleşmiştir (Cimerman, Chebabob ve Rodríguez-Morales, 2020, s. 94).

Brezilya'da Covid-19 kaynaklı olarak kayda geçen ilk ölüm 16 Mart'ta gerçekleşmiştir (BBC, 2020). Bundan sonra ölümler de vaka sayılarına benzer şekilde hızlı bir artış göstermeye başlamıştır. Brezilya'da yerel yöneticiler, DSÖ’nün önerilerini takip edip buna göre önlemler almaya çalışsalar da ulusal düzeyde bu önlemler hemen hayata geçirilmediği için pandeminin etkileri daha fazla hissedilmiştir (Croda, vd., 2020). Pandeminin başlangıcında yerel yönetimler, maske kullanmayı zorunlu tutmak, okulları tatil etmek/uzaktan eğitime geçmek ve özellikle kamu sektörü başta olmak üzere birçok sektörde evden çalışmaya geçmek gibi önlemler alırken Başkan Bolsonaro bu yöneticileri eleştirmiş (Euronews, 2020), hatta söz konusu önlemleri protesto eden insanlarla birlikte gösterilere katılmıştır. Bolsonaro'nun tutumu ülkede sağlık bakanlarının istifasına ya da görevden alınmasına da yol açmıştır (El Tiempo, 2020). Temmuz ayında yapılan Covid testi pozitif çıkan Bolsonaro (Instituto Igarapé, 2020), bu sonuçtan sonra söylemini az da olsa da değiştirmiş, virüsün varlığını ve hastalığın sıradan bir gripten fazlası olduğunu kabul etmek durumunda kalmıştır.

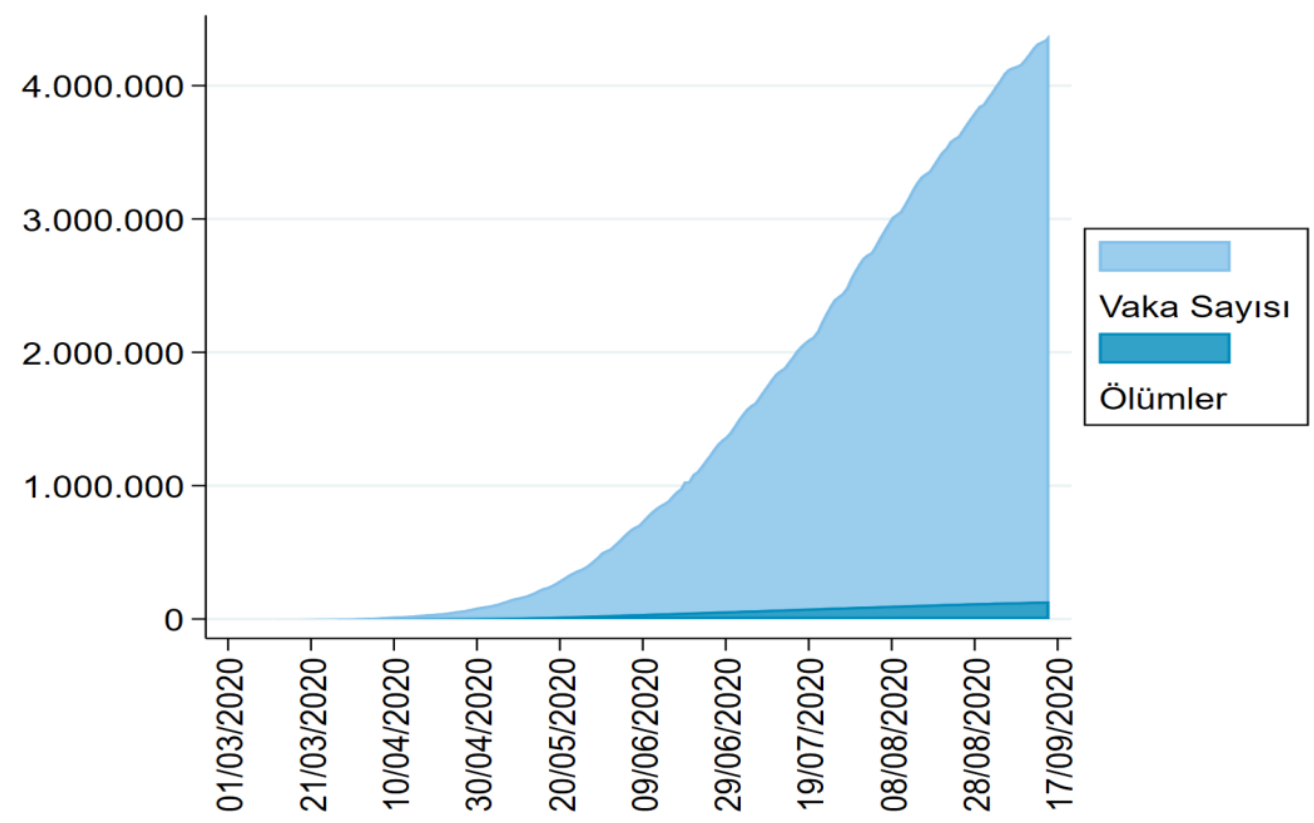

Grafik 2. Brezilya'da Covid-19 Vaka ve Ölüm Sayıları

Kaynak: Johns Hopkins Üniversitesi verileri kullanılarak yazar tarafindan oluşturulmuştur. 
Grafik 2'de görüldüğü üzere, 15 Eylül 2020 itibariyle ülkedeki toplam vaka sayısı 4 milyonu aşmıştır. Aynı dönemde 100 binden fazla insan hayatını kaybetmiştir. Net olarak ülkede 15 Eylül'e kadar toplam 4.384.299 pozitif vaka ve 133.207 ölüm bildirilmiştir. Bu tarih itibariyle Brezilya, ABD ve Hindistan'ın ardından en fazla vaka bildiren üçüncü ülke olmuştur (WHO, 2020b). Toplam pozitif vaka sayılarına göre, Covid-19 kaynaklı ölüm oranı \%3 civarındadır. Bu ise birçok ülkeye göre oldukça düşük bir orandır. Ne var ki bu olumlu bir tablo olarak değerlendirilmemelidir, çünkü enfekte olanların sayısı oldukça fazladır ve artmaya devam etmektedir. Ülke, bu çalışma için son verilerin toplandığı 15 Eylül 2020 tarihi itibariyle günlük yaklaşık 30 bin yeni vaka rapor etmektedir.

Brezilya, dünyanın en büyük ekonomilerinden biri olmasına rağmen, yoksulluğun ve ekonomik eşitsizliğin yüksek olduğu ülkelerden biridir. Brezilyalılar dünyanın en yoksul halkları arasında olmamakla birlikte (Filho ve Horridge, 2006, s. 364), yoksulluk ülkenin belli bölgelerde yoğunlaşmıştır. Ülkenin en yoksul bölgeleri kuzey ve kuzeydoğu bölgeleri iken (Soares, Souza ve Silva, 2016, s. 1), güneydoğuda yoksulluk o kadar yoğun değildir. Aynı zamanda ülkenin güneyinde ekonomik olarak daha fazla gelişmiş şehirler/bölgeler bulunmaktadır. Öte yandan büyük kentlerin eteklerinde kurulu gecekondu mahallelerinde (favela) yaşayan yaklaşık 12 milyon insanın sağlık, eğitim ve altyapı gibi hizmetlere erişimi çok kısıtlıdır. Hükümet politikalarında favelalar ve orada yaşayan halk herhangi bir öncelik taşımadığ 1 için Covid-19 bu mahallelerde yetersiz sağlık hizmetleri nedeniyle daha hızlı yayılmış; işsizlik, yoksulluk, evsizlik, yetersiz beslenme, temiz suya erişim gibi var olan sorunlar daha da derinleşmiştir. Sivil toplum örgütleri favelalarda yaşayan halka devletten çok daha yakın durumda oldukları için, gıda ve ilaç desteğiyle insanların bu süreci atlatmasına yardımcı olmaya çalışmaktadırlar (Uysal Oğuz, 2020, s. 4).

Brezilya'da 15 Eylül 2020 tarihine kadar tespit edilen Covid-19 vaka sayılarını bölgesel olarak gösteren Harita 1'e göre ülkenin güneydoğusunda vaka sayıları daha fazladır. Özellikle ülkenin en fazla gayri safi yurtiçi hasılaya (GSYİH) sahip olan São Paulo'da (De Souza, 2019) vaka sayılarının 800.000 'den fazla oluşu dikkat çekmektedir. São Paulo kent olarak yaklaşık 12 milyon, banliyöleriyle birlikte metropolitan bölgesi olarak ise 22 milyondan fazla nüfusu ile ülkenin en kalabalık şehridir (Instituto Brasileiro de Geografia e Estatistica, 2020; World Population Review, 2020b). Ülkedeki ilk Covid-19 vakası ve pandemi kaynaklı ilk ölüm bu şehirde gerçekleşmiş, virüsün yayılması daha hızlı ve kolay olmuştur. Bölgede nüfusun yüksekliği ve yoğunluğundan dolayı insanlar arası etkileşimin daha fazla olduğu göz önünde bulundurulduğunda vaka sayısının fazlalığı anlaşılabilir bir durumdur. 


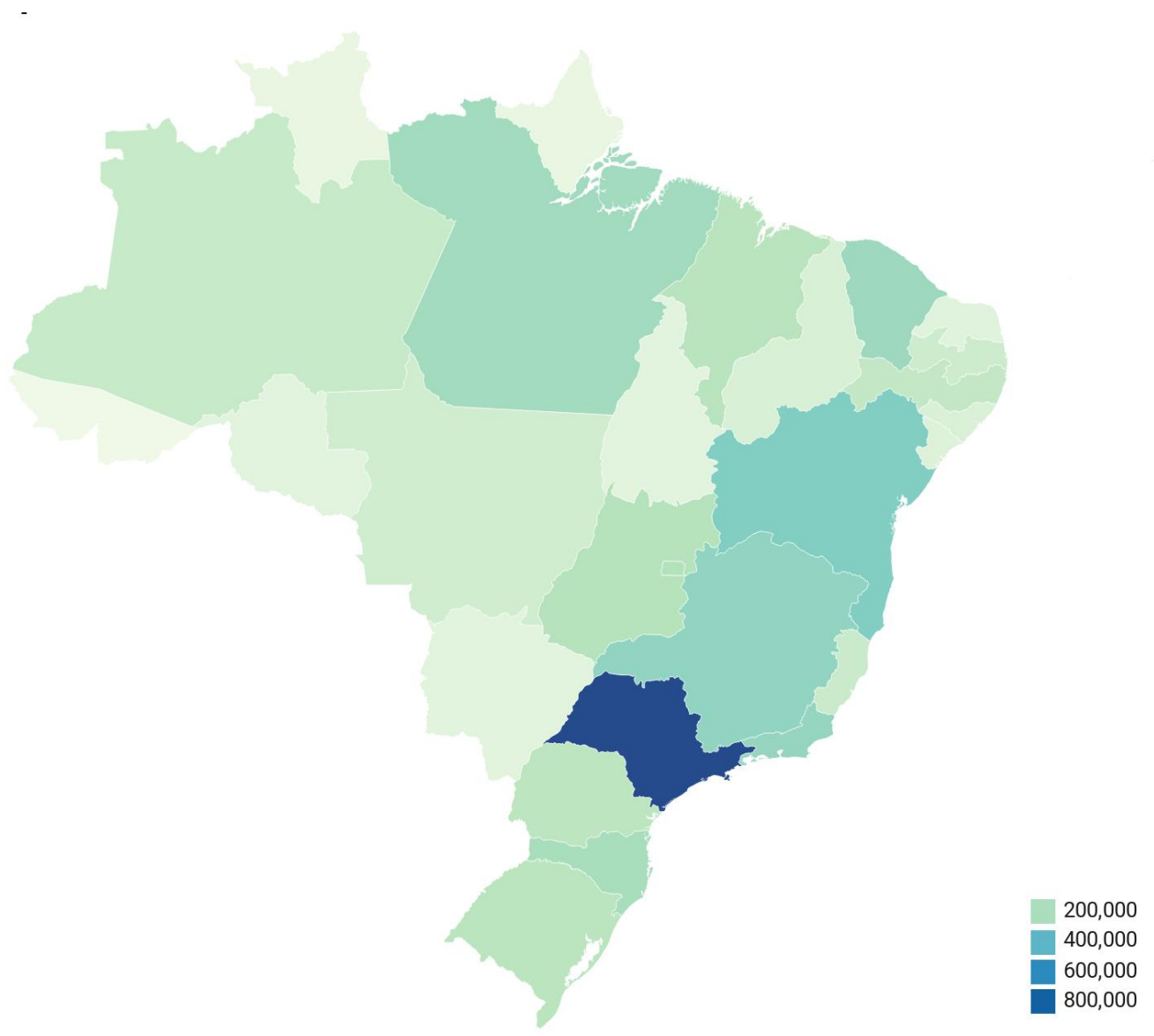

Harita 1. Brezilya'da Bölgelere göre Covid-19 Vakaları

Kaynak: Johns Hopkins Üniversitesi verileri kullanılarak yazar tarafindan oluşturulmuştur.

Harita 1 incelendiğinde vaka sayılarının, genel olarak São Paulo başta olmak üzere ülkenin güneydoğusunda yoğunlaştı̆̆ görülmektedir. Ülkenin ticari ve ekonomik merkezlerinin yoğun olduğu bu bölgelerde gerçekleşen insanlar arası etkileşim vaka sayılarının fazla olmasının nedenlerinden biridir. Buna karşın, yoksulluğun daha derin ve yoğun olduğu kuzeyde ise tespit edilen vaka sayısı daha az olarak açıklanmaktadır. Benzer şekilde, genellikle dış dünya ile bağlantının az olduğu ve yerli kabilelerinin yaşadığı Amazon bölgesinde de vaka sayıları Harita 1'de görüldüğü üzere azdır. Ne var ki, dış dünya ile bağlantısı neredeyse yok denecek kadar az olan bazı kabilelerde de Covid-19 vakalarına rastlanmıştır. Fakat ülkenin geri kalanının aksine yerli grupların virüsle mücadelesi daha kolay olmuş ve kısa süre içinde yerlilerin yaşadığı çoğu yerleşim bölgesi virüsten arındırılmıştır (Peres, 2020).

Covid-19, her ülkede olduğu gibi Brezilya'da da can kayıplarının yanı sıra birçok başka probleme de neden olmuştur. Bunların başında ekonomik sorunlar gelmektedir. Brezilya'da yoğun olan yoksulluk ve ekonomik eşitsizlik pandemi dönemiyle birlikte daha da derinleşmiştir. Sağlık ve eğitim gibi alanlarda yaşanan sorunlar ve farklı grupların bu hizmetlere erişim olanağ arasındaki uçurum da pandeminin etkisiyle artmıştır (Uysal Oğuz, 2020, s. 4). Ayrıca, Brezilya'nın birçok ülke ile sınırlarını kapatması (KPMG, 2020), ülkedeki döviz girdisini ve turizm faaliyetlerini de yavaşlatmıştır. $\mathrm{Bu}$ ise hizmet sektörünün önemli bir istihdam alanı 
olduğu ülkede işsizliğin artmasına yol açmıştır. Pandeminin ilk dört ayında yaklaşık 2 milyon kişi işini kaybetmiştir (Castro, 2020).

Yapılan açıklamalara göre, ülkede istihdamın \%17'sini oluşturan yaklaşık 50.000 turizm firması Mart-Ağustos ayları arasında çalışamamış, bar, restoran gibi yeme-içme ve eğlence yerleri kalıcı ya da geçici olarak kapanmıştır (Scalzaretto, 2020). Bunun yanı sıra ülkenin ihraç ettiği ürünlerin maddi değeri yaklaşık olarak \%15 oranında değişmiştir (ECLAC, 2020, s. 12). 2020 yılı sonuna kadar Brezilya ekonomisinde \%5,2 oranında küçülme beklendiği belirtilmiştir (ECLAC, 2020, s. 13). Ekonomide küçülme beklentisi, GSYİH'de azalma olacağının göstergelerinden biridir. Bunun yanı sıra pandeminin en yoğun olduğu aylarda enflasyon, bir önceki yılın aynı çeyreğine göre yüksek seyretmiştir (Banco Central Do Brasil, 2020).

Latin Amerika'nın yüz ölçümü olarak en büyük ve nüfus olarak en kalabalık ülkesi olan Brezilya, vaka ve ölüm sayıları açısından bölgede pandemiden en fazla etkilenen ülkedir. Aynı zamanda bölgede ilk vakanın görüldüğü ülke, 15 Eylül itibariyle 4 milyondan fazla vaka ve 130 binden fazla ölüm rapor etmiştir. Vaka sayılarına oranla ölümlerin az olması ülkede olumlu bir tablo çizse de virüsün yayılma hızı endişe vericidir. Virüsün ülkede bu denli hızlı yayılmasının en önemli nedenleri arasında, pandeminin başlangıcından itibaren Başkan Bolsonaro'nun sorumsuz söyleminin ve hükümetin izlediği bilinçsiz politikaların olduğu kabul edilmektedir. Bu nedenle Brezilya dünyada pandemiden en fazla etkilenen üçüncü ülke haline getirmiştir.

\section{Meksika}

Meksika, toplamda $1.964 .375 \mathrm{~km}^{2}$ yüz ölçümü ve 130 milyona yakın nüfusu (CIA, 2020b) ile Latin Amerika'nın en büyük ülkelerinden biridir. Bunun yanı sıra yaklaşık 2,6 trilyon USD olan GSYİH'si ile dünyanın en büyük ilk 15 ekonomisi arasında yer almaktadır (T.C. Ticaret Bakanlığı, 2020). Buna rağmen ülkede ekonomik eşitsizlik ve yoksulluk en önemli sorunlardan biridir ve son yıllarda ekonomik büyüme hızı yavaşlamaya başlamıştır (Index of Economic Freedom, 2020). Meksika da Brezilya gibi Latin Amerika'nın sanayileşmiş birkaç ülkesinden biridir.

\subsection{Meksika'nın Sosyoekonomik Yapısı}

Brezilya'da olduğu gibi Meksika'nın da karşı karşıya bulunduğu ekonomik, toplumsal ve siyasal sorunların kaynaklarından birisi ülkenin sömürge geçmişidir. 1519'da Meksika'ya ulaşan İspanyol fatih Hernán Cortes, Aztek İmparatorluğu'nu yıkarak 1521'de İspanya Krallı̆̆ adına bu toprakları ele geçirmiştir. (Hamilton, 2015, s. 317). Meksika topraklarının madenler bakımından zengin olması nedeniyle İspanya Krallığ (Embassy of Mexico United Kingdom, t.y.). Sömürge döneminin başlangıcından itibaren geliştirilen ticari ilişkiler Meksika'yı ham madde tedarikçisi olmaktan öteye taşımamış, ekonomik olarak İspanya'ya bağımlı hale getirmiştir (Foster, 2007, s. 64-67). Bu ise uzun vadede Meksika'da ortaya çıkan ekonomik problemlerin temellerini oluşturmuştur.

Meksika, 1821'de İspanya'ya karşı verdiği bağımsızlık savaşını kazanmıştır (Kirkwood, 2000). Tüm Latin Amerika ülkelerine benzer biçimde karma bir nüfus yapısına sahip olan Meksika'da var olan toplumsal ayrımlar bağımsızlıktan sonra derinleşmiştir. Bu toplumsal ayrışmaların varlığı zaman içinde bazı etnik grupları toplumsal piramidin üst katmanlarına 
taşımıştır. Bu ise yine Brezilya'da olduğu gibi Meksika'da da elitler siyasetini doğurmuştur (Skidmore ve Smith, 2005, s. 36).

Meksika bağımsızlık ilanından kısa bir süre sonra ilk anayasasını oluşturmuştur (Hamnett, 2004, s. 144). Fakat bağımsızlığın ilk yıllarında, sömürge döneminden kalma toplumsal ayrışmanın da etkisiyle, ülkede sürekli iç çatışmalar ve siyasi krizler hâkim olmuştur (Foster, 2007, s. 135). Meksika'da 19. yüzy1l boyunca demokrasi geliştirilmeye çalış1lmışsa da 1876 'da General Porfirio Díaz'in darbe ile işbaşına gelmesi, uzun yıllar sürecek olan otoriter bir yönetime yol açmış ve bu da 1910 'da başlayan Meksika Devrimi'ne zemin hazırlamıştır (Emmerich, 2010, s. 250). Meksika Devrimi dönemin diktatörlüğüne son verme ve ülkedeki ekonomik eşitsizliği ortadan kaldırma gibi temel hedefler ile ortaya çıkmıştır (Kirkwood, 2000, s. 132).

Meksika Devrimi ve onu izleyen ayaklanmalar sonucunda ülkedeki siyasi yapı da şekillenmiştir. 1917'de yeni anayasa kabul edilmiş ancak ülkenin siyasi yapısı beklendiği gibi demokratikleşmemiştir. 1929'dan 2000 yılına kadar yapılan seçimleri kazanan Kurumsal Devrimci Parti (PRI) tek başına iktidarını sürdürmüştür (Knight, 2008, s. 7). Her ne kadar ülke siyasi olarak tek bir partinin yönetiminde olsa da bu dönemin özellikle ekonomik anlamda getirileri olmuştur ve Meksika önemli bir kalkınma hamlesi başlatmıştır (Hamnett, 2004, s. 259). 1990'ların sonuna gelindiğinde ekonomik krizler ve toplumsal ayaklanmalar ile karş1 karşıya PRI bir hayli güç kaybına uğramış ve 2000 seçimlerini Ulusal Hareket Partisi'nin kazanmasıyla Meksika'nın siyasi çehresi değişmiştir (Skidmore ve Smith, 2005, s. 292).

2000'li yıllarda daha istikrarlı ve kalkınma odaklı bir siyaset izleyen Meksika'da, 2018'de Ulusal Yenilenme Hareketi (MORENA) aday1 Andrés Manuel López Obrador'un başkan seçilmesi ile sol eğilimli bir yönetim iktidara gelmiştir (Ahmed ve Villegas, 2018). López Obrador göreve başladığı ilk yıl, ülkede özellikle yoksul kesime sağladığı destek ile dikkat çekmiştir (Gobierno de Mexico, 2020). Toplumsal ve ekonomik dönüşümün sağlanmas1, yolsuzluk ve seçim suçlarına verilen cezaların artırılması, üst düzey hükümet görevlilerinin maaşlarını azaltmak için tasarruf planı uygulanması, emekli maaşlarının yükseltilmesi, altyapı harcamalarının artırılarak yerli tarım sektörünün canlandırılması gibi iç politika hedefleri belirleyen López Obrador (Ersoy ve Cantu Garza, 2019, s. 455-456), dış politikada ise başlarda Trump ve ABD karşıtı söylemleri ile ön plana çıksa da ilerleyen süreçte giderek daha popülist politikalar izlemekle eleştirilmiştir (Márquez, 2020).

Bolsonaro gibi López Obrador da Covid-19 pandemisinin başlarında süreci yeterince önemsememiş ve Meksika halkını alınması gereken önlemler konusunda uyarmak yerine “dualar” ile virüsün üstesinden gelebileceklerini söylemiştir (Navarro, 2020). Öyle ki, López Obrador da pandeminin ilk dönemlerinde katıldığı etkinliklerde Bolsonaro gibi maske dahi kullanmamış ve halka olumsuz örnek olmuştur. Yine benzer şekilde, López Obrador da sosyal mesafenin önemini vurgulamak yerine bunun gereksiz olduğunu dile getirmiştir (Felbab-Brown, 2020). Başkanın pandemiyi önemsemeyen söylemi ve tutumu, başlarda Meksika halkının da tavrını etkilemiş ve virüsün ülkede hızlı bir şekilde yayılmasının nedenlerinden biri olarak görülmüştür. 


\subsection{Meksika'da Covid-19 Pandemisi ve Etkileri}

Meksika'da ilk Covid-19 pozitif vakası 27 Şubat 2020'de ülkenin başkenti Meksiko'da görülmüştür (Suárez, Quezada, Ruiz ve De Jesús, 2020, s. 4). İlk vakadan itibaren yeni vakalar hızlı bir şekilde artmış ve virüsten kaynaklı ölümler başlamıştır. Ülkede Covid-19 kaynaklı ilk can kaybı 9 Mart'ta rapor edilmiş (CNN Español, 2020), sonrasında ölüm sayıları hızla yükselmiştir. Öyle ki, Temmuz ayı sonunda ölüm sayıları bakımından ABD ve Brezilya'nın ardından dünyada üçüncü sıradaki ülke Meksika olmuştur (DW, 2020). Ülkenin bu kötü durumunda, López Obrador'un virüs konusundaki tutumu, ekonominin ayakta kalabilmesi için hayatın eskiden olduğu gibi devam etmesi gerektiği gerekçesiyle hükümet tarafından sıkı kısıtlamalar uygulanmaması ve sağlı sisteminin Covid-19 ile mücadele etmede yetersiz kalmas1 etkili olmuştur (Agren, 2020a).

Grafik 3'te görüldüğü üzere, 15 Eylül 2020 itibariyle Meksika toplamda, 676.487 pozitif vaka ve 71.678 ölüm rapor etmiştir. Bu tarihte Meksika, bölgede en fazla ölüm bildiren ülke olmuştur. Özellikle toplam vaka sayısı ile oranlandığından ülkedeki ölüm oranları oldukça yüksektir. Toplam pozitif vakalara göre ölüm oranı yaklaşık \%10'dur. Bu ise hem bölgedeki hem de dünyadaki birçok ülkeye göre son derece yüksek bir orandır. Bu çalışmanın tamamlandığı 15 Eylül 2020 tarihinde Meksika'da rapor edilen yeni vaka sayısı 4 binden fazla olmuştur.

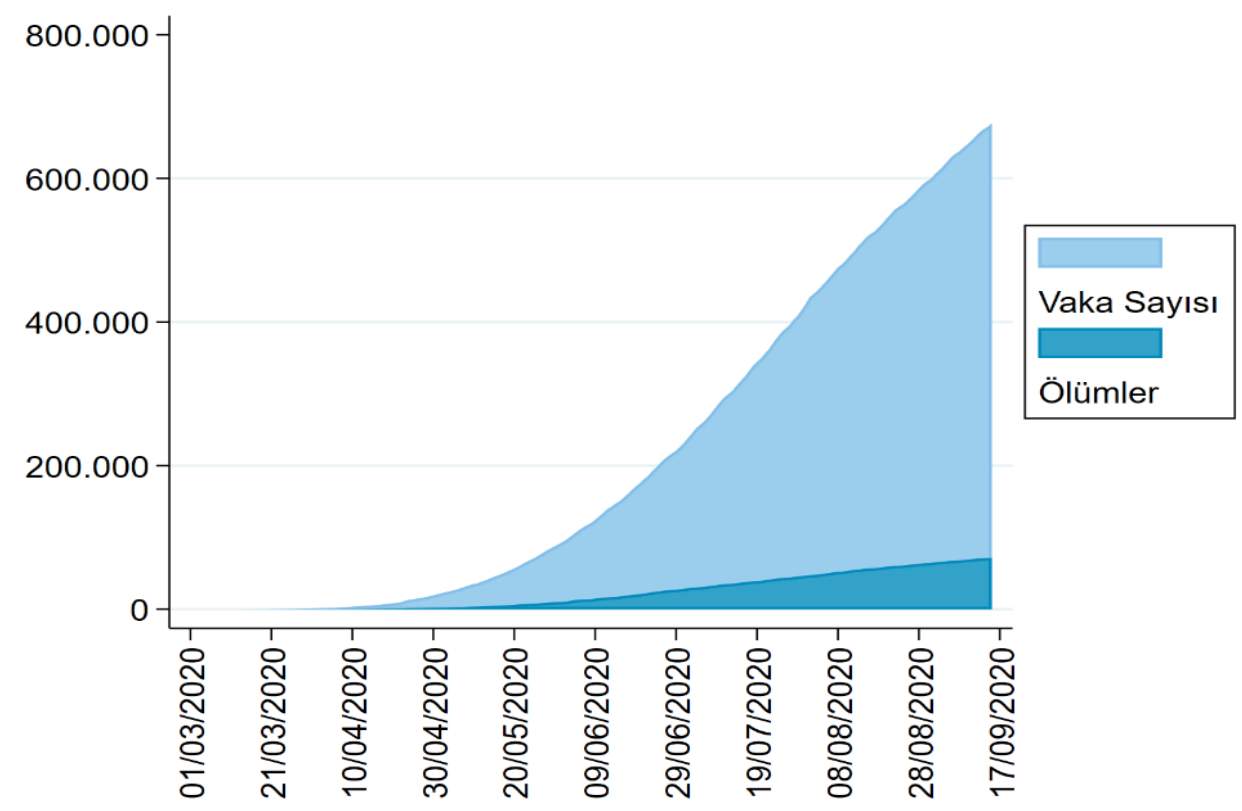

Grafik 3. Meksika'da Covid-19 Vaka ve Ölüm Sayılar

Kaynak: Johns Hopkins Üniversitesi verileri kullanılarak yazar tarafindan oluşturulmuştur.

Meksika, dünyanın ve Latin Amerika'nın büyük ekonomilerinden biri olmasına rağmen, yoksulluğun ve ekonomik eşitsizliğin yüksek olduğu ülkelerden biridir (Alvarado, 2008). Bununla birlikte, son yıllarda eşitsizliği ve yoksulluğu azaltmak için çeşitli politikalar hayata 
geçirilmeye başlanmıştır. Yoksulluk ülkenin güneyinde daha yoğunken (CONEVAL, t.y., s. 9), kuzey eyaletlerinde gelir ve refah seviyesi nispeten daha yüksektir.

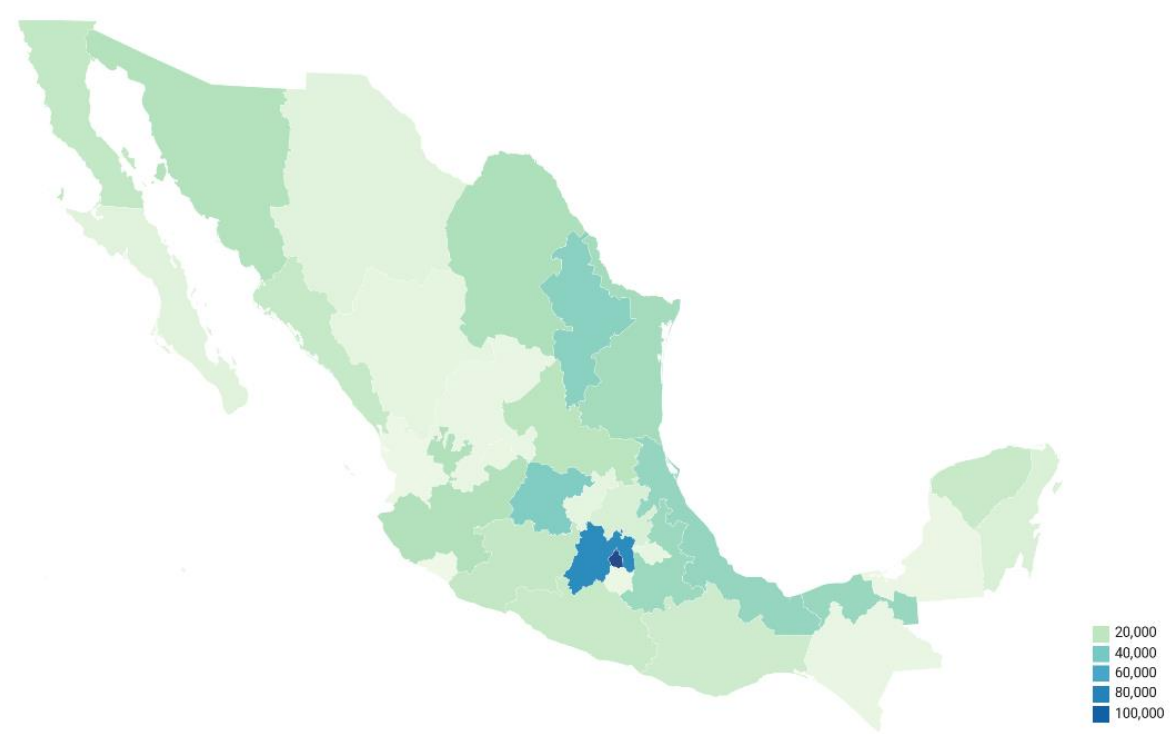

Harita 2. Meksika'da Bölgelere göre Covid-19 Vakaları

Kaynak: Johns Hopkins Üniversitesi verileri kullanılarak yazar tarafından oluşturulmuştur.

Meksika'da 15 Eylül 2020 tarihine kadar bölgesel Covid-19 vaka sayılarını gösteren Harita 2'ye göre, ülkenin güneybatısında ve kuzeydoğusunda tespit edilen vakalar diğer bölgelere göre daha fazladır. Bu noktada başkent Meksiko bir istisna oluşturmaktadır. Çünkü Harita 2'de de görüldüğü gibi en çok vaka başkentte tespit edilmiştir. Ayrıca ülkedeki ilk Covid-19 vakası ve can kaybı da başkentte gerçekleşmiştir. Vaka sayılarının Meksiko'da yüksek olmasının en önemli nedenlerinden birisi, en çok testin burada yapılıyor olmasıdır. Bununla birlikte başkentin çevresindeki banliyölerle birlikte metropolitan nüfusunun 21 milyondan fazla olması (World Population Review, 2020a), insanların yoğun etkileşimi dolayısıyla virüsün yayılmasını artıran unsurlardan bir diğeridir. Öte yandan pandeminin başından itibaren ülke genelinde günlük yapılan ortalama test sayısının çok az oluşu ise uzmanlar tarafindan eleştirilmiştir. Kimi yorumlara göre Başkan López Obrador'un pandemiye yaklaşımı, hükümetin nüfusun büyük bölümünün ekonomik olarak olumsuz etkileneceği genel bir kapanma ve karantinadan kaçınmak istemesi ve testleri yüksek maliyetli olarak görmesi bunun nedenleri arasında yer almaktadır (Agren, 2020b).

Meksika'da Covid-19 vakaları genellikle ülkenin ticaret merkezlerinde yoğunlaşmıştır. Örneğin Chiapas (ülkenin en güneyi) gibi görece daha yoksul olan ve ağırlıklı olarak yerlilerin yaşadığı bölgelerde vaka sayıları çok yüksek olarak görülmemekte, çoğu yerde test sayısının yetersizliği nedeniyle vakaların tespit edilmesinde güçlükler yaşanmaktadır. Pandemi ülkede ciddi ekonomik ve sosyal sorunlara da yol açmıştır. Özellikle, ithalata ve ihracata dayalı iş yapan firmalar ile küçük işletmeler süreçten çok fazla etkilenmiştir (The World Bank, 2020). Bunun yanı sıra pandeminin etkisiyle GSYİH azalmaya başlamış, işsizlik ise artmıştır (INEGI, 2020). Ülkenin turizm gelirleri ve döviz girdisinde de düşüş görülmektedir (INEGI, 2020). 
Latin Amerika'nın en fazla nüfusa sahip ikinci ülkesi olan Meksika, bölgede Brezilya'nın ardından pandemiden en çok etkilenen ülkedir. 15 Eylül 2020 itibariyle vaka sayıları çok yüksek olmasa da rapor edilen Covid-19 kaynaklı ölümler hem bölgeye hem de dünya geneline göre oldukça yüksektir. Başlangıçta hükümetin ve dolayısıyla halkın, durumun ciddiyetini yeterince kavramamış olması ülkedeki yüksek ölüm oranının nedenlerinden biri olarak görülmektedir. Bu yaklaşım Meksika'nın Covid-19 kaynaklı ölümlerde dünyada üçüncü sıraya yükselmesine yol açmıştır.

\section{Sonuç}

Tüm dünyayı hızla etkisi altına alan Covid-19 pandemisi Latin Amerika ülkelerinin büyük bölümünde vaka ve ölüm sayılarının artışı ve olumsuz sosyoekonomik sonuçlarıyla derin şekilde hissedilmektedir. Pandemiye karşı birçok ülkede hükümetlerin izlediği politikalar benzerlik göstermektedir. Bu süreçte alınan kapsamlı önlemlerin kimi zaman etkisini gösterdiği, pandeminin hızının bazı ülkelerde kontrol altına alındığı görülmektedir. Bu çalışmada incelenen 1 Mart 2020 ile 15 Eylül 2020 tarihleri arasında, Latin Amerika'da en yüksek vaka ve ölüm sayısına sahip olduğu belirlenen Brezilya ile en yüksek ölüm oranına sahip olan Meksika'da yönetimlerin halk sağlığını koruyacak önlemleri yeterli derecede ve zamanında almaması söz konusudur.

Çalışmada kullanılan son verilerin derlendiği 15 Eylül 2020 tarihi itibariyle Brezilya'da 4 milyonun üzerinde vaka ve 130 binden fazla ölüm gerçekleşirken, bu sayılarla ülke ABD'nin ardından dünyada ikinci sırada yer almıştır. Meksika'da ise aynı tarihte 700 bine yakın vaka rapor edilmiş, 70 binden fazla insanın hayatını kaybettiği açıklanmıştır. Çalışmanın tamamlanmasının ardından geçen sürede bu sayılar değişkenlik göstermiş olsa da her iki ülkede vaka ve ölüm sayılarının artmaya devam ettiğini ve önlemlerin yetersiz kaldığını söylemek yanlış olmayacaktır.

Brezilya'daki popülist sağ Bolsonaro hükümeti ve Meksika'daki popülist sol López Obrador hükümeti, siyasi yelpazenin farklı noktalarında yer almalarına rağmen, pandemi karşısında benzer şekilde başarısız politikalar izlemişlerdir. Her iki devlet başkanı da pandemiyi, özellikle başlangıçta önemsememiş, katı önlemler almaktan kaçınmıştır. Bolsonaro Covid-19'u basit bir gribe benzetirken, López Obrador halkın dua ile virüsü yenebileceğini ileri sürmüştür. Bu söylem halkın bir bölümü tarafından pandeminin yeterince ciddiye alınmamasına yol açmıştır. Öte yandan özellikle Brezilya'da kimi yerel yönetimlerin daha sıkı önlemler alma kararı Bolsonaro tarafından şiddetle eleştirilmiştir. Pandemi sürecinde milyonlarca insan başka seçeneği olmadığ için çalışmaya devam etmiş ve enfekte olma riskiyle karşı karşıya kalmıştır. Dolayısıyla, bu çalışmada Covid-19 pandemisinin Latin Amerika'da halihazırda var olan sınıfsal uçurumu derinleştirdiği, incelenen iki ülke ekonomisinin de pandemi sürecinden son derece olumsuz etkilendiği ve sosyoekonomik olarak dezavantajlı kesimler üzerinde pandeminin daha yıkıcı etkiler doğurduğu görülmüştür. Latin Amerika'nın iki büyük ekonomisi olan Brezilya ve Meksika'da popülist liderlerin pandemiye yönelik söylem ve tutumları ülkelerin virüs ile baş etmekte kapasitesini de olumsuz etkilemiştir. Bu nedenle her iki ülkede de popülist yönetim anlayışının sorgulanması gereklidir. Sonuç olarak, izlenen politikalarda önemli değişikliğe gidilmediği takdirde devam eden pandemi sürecinin Latin Amerika'da ve bu çalışma özelinde Brezilya ve Meksika'da ilerleyen süreçte de olumsuz siyasi, toplumsal ve ekonomik gelişmelere yol açacağı öngörülebilir. 


\section{Kaynakça}

Agren, D. (2020a). Coronavirus advice from Mexico's president: 'Live life as usual'. Retrieved from https://www.theguardian.com/world/2020/mar/25/coronavirus-advice-from-mexicos-presidentlive-life-as-usual

Agren, D. (2020b). Mexico flying blind as lack of Covid-19 testing mystifies experts. Retrived from https://www.theguardian.com/global-development/2020/jul/24/mexico-covid-19-testingcoronavirus

Ahmed, P. A. and Villegas, P. (2018). López Obrador gana la presidencia de México con una victoria aplastante. Retrieved from https:/www.nytimes.com/es/2018/07/02/espanol/americalatina/eleccion-2018-amlo-lopez-obrador.html

Alvarado, E. (2008). Poverty and inequality in Mexico after NAFTA: Challenges, setbacks and implications. Estudios fronterizos, 9(17), 73-105. doi:10.21670/ref.2008.17.a03

Andrus, J. K., Evans-Gilbert, T., Santos, J. I., Guzman, M. G., Rosenthal, P. J., Toscano, C., ... Breman, J. G. (2020). Perspectives on battling COVID-19 in countries of Latin America and the Caribbean. The American Society of Tropical Medicine and Hygiene, 103(2), 593-596. doi:10.4269/ajtmh.200571

Argentina Presidencia Ministerio de Salud. (2020). Reporte diario vespertino nro 370 situación de Covid19 Argentina. Retrieved from https:/www.argentina.gob.ar/sites/default/files/15-09-20-reportevespertino-covid-19.pdf

Banco Central Do Brasil. (2020). Economic outlook-inflation. Retrieved from https://www.bcb.gov.br/en

BBC. (2020). Coronavirus: First Brazil death 'earlier than thought'. Retrieved from https://www.bbc.com/news/world-latin-america-52638352

Bedford, J., Enria, D., Giesecke, J., Heymann, D. L., Ihekweazu, C., Kobinger, G., ... Wieler, L. H. (2020). COVID-19: towards controlling of a pandemic. The Lancet, 395(10229), 1015-1018. doi:10.1016/S0140-6736(20)30673-5

Blofield, M., Hoffmann, B. and Llanos, M. (2020). Assessing the political and social impact of the COVID-19 Crisis in Latin America. GIGA Focus | Latin America (3), 1-13. Retrieved from https://www.ssoar.info/

Bolivia Ministerio de Salud. (2020). Ministerio de Salud reporta 667 contagios nuevos de COVID-19 y el total sube a 128.286. Retrieved from https:/www.minsalud.gob.bo/4616-ministerio-de-saludreporta-667-contagios-nuevos-de-covid-19-y-el-total-sube-a-128-286

Burki, T. (2020). COVID-19 in Latin America several problems undermine the preparedness of countries in Latin America to face the spread of Covid. The Lancet Infectious Diseases, 20(5), 547-548. doi:10.1016/S1473-3099(20)30303-0

Caicedo-Ochoa, Y., Rebellón-Sánchez, D. E., Peñaloza-Rallón, M., Cortés-Motta, H. F. and MéndezFandiño, Y. R. (2020). Effective reproductive number estimation for initial stage of COVID-19 pandemic in Latin American countries. International Journal of Infectious Diseases, (96), 316318. https://doi.org/10.1016/j.ijid.2020.04.069

Castro, J. R. (2020). How has the Covid-19 pandemic affected Brazil's different regions?. Retrieved from https://labsnews.com/en/articles/society/how-has-the-covid-19-pandemic-affected-brazilsdifferent-regions/

CDE. (2020). WHO says Latin America has become the epicentre of the coronavirus pandemic. Retrieved from https://cde.news/who-says-latin-america-has-become-the-epicentre-of-the-coronaviruspandemic/

Central Intelligence Agency (2020b). The world factbook Mexico. Retrieved from https://www.cia.gov/library/publications/the-world-factbook/geos/mx.html

Central Intelligence Agency. (2020a). The world factbook Brazil. Retrieved from https://www.cia.gov/library/publications/the-world-factbook/geos/br.html 
Cimerman, S., Chebabob, A. and Rodríguez-Morales, C. A. (2020). Deep impact of COVID-19 in the healthcare of Latin America: The case of Brazil. The Brazilian Journal of Infection Diseases, 24(2), 93-95. doi:10.1016/j.bjid.2020.04.005

CNN Español. (2020). México reporta primera muerte por coronavirus. Retrieved from https://cnnespanol.cnn.com/2020/03/19/secretaria-de-salud-de-mexico-reporta-primera-muertepor-coronavirus/

CONEVAL. (t.y.). Multidimensional measurement of poverty in Mexico: An economic wellbeing and social rights approach. Mexico City: Consejo Nacional de Evoluacion de la Politica de Desarrollo Social. Retrieved from https://www.coneval.org.mx/InformesPublicaciones/FolletosInstitucionales/Documents/Multidime nsional-Measurement-of-poverty-in-Mexico.pdf

Croda, J., Oliveira, W. K., Frutuoso, R. L., Mandetta, L. H., Baia-da-Silva, D. C., Brito-Sousa, J. D., ... Lacerda, M. V. (2020). COVID-19 in Brazil: advantages of a socialized unified health system and preparation to contain cases. Revista da Sociedade Brasileira de Medicina Tropical, (53), 1-6. doi:10.1590/0037-8682-0167-2020

De Souza, D. P. (2019). City of São Paulo has GDP of 4.3 thousand Brazilian municipalities together. Retrieved from https://agenciadenoticias.ibge.gov.br/en/agencia-news/2184-newsagency/news/26407-pib-da-cidade-de-sao-paulo-equivale-ao-da-soma-de-4-3-mil-municipiosbrasileiros-2

Dellanna, A. (2020). Coronavirus: South America 'a new epicentre' of the pandemic, WHO says. Retrieved from https://www.euronews.com/2020/05/23/coronavirus-latin-america-a-newepicentre-of-the-pandemic-who-says

Doğanyılmaz Duman, D. (2020). Popülist söylemin seçmen davranışlarına etkisi: Jair Bolsonaro'nun seçim kampanyasının incelenmesi. Uluslararası İktisadi ve İdari İncelemeler Dergisi, (27), 193208. https://doi.org/10.18092/ulikidince.649520

DW. (2020). México ya es el tercer país con más muertos por COVID. Retrieved from https://www.dw.com/es/m\%C3\%A9xico-ya-es-el-tercer-pa\%C3\%ADs-con-m\%C3\%A1s-muertospor-covid/a-54399918

Economic Commission for Latin America and the Caribbean. (2020). Report on the economic impact of Coronavirus Disease (COVID-19) on Latin America and the Caribbean. Retrieved from https://repositorio.cepal.org/bitstream/handle/11362/45603/1/S2000312_en.pdf

Edwards, T. L. (2008). Brazil: A global studies handbook. California: ABC-CLIO.

El Tiempo. (2020). La crisis de los ministros en la era de Jair Bolsonaro en Brasil. Retrieved from https://www.eltiempo.com/mundo/latinoamerica/por-que-han-renunciado-cuatro-ministros-algobierno-de-bolsonaro-en-brasil-509240

Embassy of Mexico United Kingdom. (t.y.). Colonial Mexico. Retrieved from https://embamex.sre.gob.mx/reinounido/images/stories/PDF/Meet_Mexico/9_meetmexicocolonialmexico.pdf

Emmerich, G. E. (2010). The state of democracy in Mexico. Norteamérica, 5(1), 247-285. https://doi.org/10.22201/cisan.24487228e.2010.01.17

Ersoy, G. ve Cantu Garza, L. (2019). Meksika. C. Uysal Oğuz, S. Atvur, R. İzol (Ed.), 21. Yüzyılda Latin Amerika: Siyaset, Ekonomi, Toplum içinde (s. 441-461). Ankara: Seçkin.

Estadísticas Venezuela. (2020). Estadísticas Venezuela. Retrieved from https://covid19.patria.org.ve/estadisticas-venezuela/

Euronews. (2020). El presidente de Brasil critica las medidas de prevención adoptadas en Sao Paulo y Río de Janeiro. Retrieved from https://es.euronews.com/2020/03/25/el-presidente-de-brasil-criticalas-medidas-de-prevencion-adoptadas-en-sao-paulo-y-rio-de

Felbab-Brown, V. (2020, March 30). AMLO's feeble response to COVID-19 in Mexico [Blog]. Retrieved from https://www.brookings.edu/blog/order-from-chaos/2020/03/30/amlos-feeble-response-tocovid-19-in-mexico/ 
Filho, J. B. and Horridge, M. J. (2006). Economic integration, poverty and regional inequality in Brazil. Revista Brasileira de Economia, 60(4), 363-387. doi:10.1590/S0034-71402006000400003

Foster, L. V. (2007). A brief history of Mexico. New York: Checkmark Books.

Gobierno de Mexico. (2020). AMLO. Retrieved from https://lopezobrador.org.mx

Hamilton, N. (2015). Mexico. In H. E. Vanden and G. Prevost (Eds.), Politics of Latin America: The power game (pp. 315-341). New York: Oxford University Press.

Hamnett, B. (2004). A concise history of Mexico. Cambridge: Cambridge University Press.

Horwitz, L., Nagovitch, P., Sonneland, H. K. and Zissis, C. (2020). The Coronavirus in Latin America. Retrieved from https://www.as-coa.org/articles/coronavirus-latin-america\#argentina

Hunter, W. and Power, T. J. (2019). Bolsonaro and Brazil's illiberal backlash. Journal of Democracy, 30(1), 68-82. Retrieved from https://muse.jhu.edu/

Index of Economic Freedom. (2020). Mexico. Retrieved from https://www.heritage.org/index/country/mexico

INEGI. (2020). Empleo y Ocupacion. Retrieved from https://www.inegi.org.mx/\#

Instituto Brasileiro de Geografia e Estatistica. (2020). São Paulo. Retrieved from https://www.ibge.gov.br/cidades-e-estados/sp/sao-paulo.html

Instituto Igarapé. (2020). Brazil's Bolsonaro tests positive for Coronavirus. Retrieved from https://igarape.org.br/en/brazils-bolsonaro-tests-positive-for-coronavirus/

Investopedia. (2020). Countries by GDP. Retrieved from https://www.investopedia.com/insights/worldstop-economies/

Johns Hopkins University. (2020). Coronavirus research center. Retrieved from https://coronavirus.jhu.edu/map.html

Kirkwood, B. (2000). The history of Mexico. London: Greenwood Press.

Knight, A. (2008). Mexico, c. 1930-46. In L. Bethell (Ed.), Latin America since 1930: Mexico, Central America and the Caribbean. Cambridge: Cambridge University Press.

KPMG. (2020). Brazil - Travel restrictions and other measures to confront COVID-19 crisis. Retrieved from https://home.kpmg/xx/en/home/insights/2020/03/flash-alert-2020-119.html

Lotta, G., Wenham, C., Nunes, J. and Pimenta, D. N. (2020). Community health workers reveal COVID19 disaster in Brazil. The Lancet, 396(10248), 365-366. https://doi.org/10.1016/S01406736(20)31521-X

Mahiroğulları, A. (2016). Askeri darbeler döneminden sivil demokrasi dönemine Brezilya'da sendikacılık. Sosyal Siyaset Konferanslarl, 70(1), 81-103. Erişim adresi: https://dergipark.org.tr/tr/pub/iusskd

Márquez, S. (2020). ¿Es populista López Obrador? Retrieved from https://www.eluniversal.com.mx/opinion/solange-marquez/es-populista-lopez-obrador

Meade, T. A. (2004). A brief history of Brazil. New York: Infobase Publishing.

Mendonça, R. F. and Lavalle, A. G. (2019). Brazil, 40 Years of struggles over political legitimacy through the lenses of representation. Representation, 55(3), 239-250. doi:10.1080/00344893.2019.1679241

Ministerio de Salud y Protección Social. (2020). CORONAVIRUS (COVID-19). Retrieved from https://www.minsalud.gov.co/salud/publica/PET/Paginas/Covid-19_copia.aspx

Ministerio de Salud. (2020). Reporte COVID-19 - martes 15 de septiembre 2020. Retrieved from https://www.minsal.cl/reporte-covid-19-martes-15-de-septiembre-2020/

Ministerio Salud de Pública. (2020). Coronavirus Covid-19. Retrieved from https://www.salud.gob.ec/coronavirus-covid-19/ 
Minsa. (2020). Casos confirmados por coronavirus Covid-19 ascienden a 744400 en el Perú (Comunicado $N^{\circ} 241$ ). Retrieved from https://www.gob.pe/institucion/minsa/noticias/302869minsa-casos-confirmados-por-coronavirus-covid-19-ascienden-a-744-400-en-el-peru-comunicadon-241

Navarro, M. F. (2020). Esta es la estrategia de AMLO para no contagiarse de Covid-19, según LópezGatell. Retrieved from https://www.forbes.com.mx/politica-estrategia-amlo-no-contagiarse-covid19-lopez-gatell/

Newey, S. (2020). Latin America has become the epicentre of the Coronavirus pandemic, WHO says. Retrieved from https://www.telegraph.co.uk/global-health/science-and-disease/latin-america-hasbecome-epicentre-coronavirus-pandemic-says/

Özdemir, M. (2020). Corona Virüsü Latin Amerika'da da Etkisini Arttırıyor. Erişim adresi: https://www.amerikaninsesi.com/a/corona-virusu-latin-amerikada-da-etkisiniarttiriyor/5354196.html

Panduro-Correa, V., Arteaga-Livias, K. and Rodríguez-Morales, A. J. (2020). Coronavirus Disease 2019 (COVID-19) and surgical recommendations in Latin America. The American Surgeon, 86(6), 596598. https://doi.org/10.1177/0003134820927313

Peres, E. (2020). Brazil indigenous group celebrates 6 months without COVID-19. Retrieved from https://apnews.com/article/brazil-virus-outbreak-archive-0d03018fbfbc9a0e4acfb354b2a9c699.

Polat, Y. K. (2019). Brezilya. C. Uysal Oğuz, S. Atvur, R. İzol (Ed.), 21. Yüzyılda Latin Amerika: Siyaset, Ekonomi, Toplum içinde (s. 581-604). Ankara: Seçkin.

Rodrigues, G. M. (2019). ¿El Trump Del Trópico? Política exterior de ultraderecha en Brasil (Analisis Carolina). Retrieved from https://www.fundacioncarolina.es/wp-content/uploads/2019/04/AC6.es_.pdf

Saad-Filho, A. and Boffo, M. (2020). The corruption of democracy: Corruption scandals, class alliances, and political authoritarianism in Brazil. Geoforum, 1-10. https://doi.org/10.1016/j.geoforum.2020.02.003

Sakurai, S. N. and Menezes-Filho, N. (2011). Opportunistic and partisan election cycles in Brazil: New evidence at the municipal level. Public Choice, (148), 233-247. doi:10.1007/s11127-010-9654-1

Sauer, L. M. (2020). What is Coronavirus? Retrieved from https://www.hopkinsmedicine.org/health/conditions-and-diseases/coronavirus

Scalzaretto, N. (2020). Brazil loses nearly 50,000 tourism companies amid pandemic. Retrieved from https://brazilian.report/coronavirus-brazil-live-blog/

Schwartz, S. B. (2010). The historiography of early modern Brazil. Oxford Handbooks Online. doi:10.1093/oxfordhb/9780195166217.013.0004

Secchi, L. (2016). Policy analysis in Brazil: A comparison of rationalist and argumentative approaches. Journal of Comparative Policy Analysis: Research and Practice, 18(1), 88-101. doi:10.1080/13876988.2015.1126972

Skidmore, T. E. and Smith, P. H. (2005). Modern Latin America. New York: Oxford University Press.

Skynews. (2020). Coronavirus: Brazil's president rejects COVID-19 as a 'little flu' and ignores distancing rules. Retrieved from https://news.sky.com/story/coronavirus-brazils-president-rejectscovid-19-as-a-little-flu-and-ignores-distancing-rules-11971799

Soares, S., Souza, L. D. and Silva, W. J. (2016). Poverty profile: The rural North and Northeast regions of Brazil (Working Paper 138). Retrieved from https://ipcig.org/pub/eng/PRB50_Poverty_profile_the_rural_North_Northeast_regions_of_Brazil.p df

Suárez, V., Quezada, M. S., Ruiz, S. O. and De Jesús, E. R. (2020). Epidemiology of COVID-19 in Mexico: from the 27th of February to the 30th of April 2020. Revista Clínica Española, 220(8), 110. https://doi.org/10.1016/j.rce.2020.05.007 
T. C. Ticaret Bakanlığı. (2020). Meksika ekonomisi 2020 yılının ilk çeyreğinde yıllık bazda \%2,4 küçüldü. Retrieved from https://ticaret.gov.tr/blog/ulkelerden-ticari-haberler/meksika/meksika-ekonomisi2020-yilinin-ilk-ceyreginde-yillik-bazda-2-4-kuculdu

Tekin, S. (2017). Latin Amerika'da muhafazakârlık ve diş politika: Brezilya örneği. Muhafazakâr Düşünce, 14(51), 83-105. Erişim adresi: https://dergipark.org.tr/tr/pub/muhafazakar

The World Bank. (2020). Mexico Overview. Retrieved from https://www.worldbank.org/en/country/mexico/overview

Uysal Oğuz, C. (2020). Latin Amerika'da COVID-19 ve derinleşen sorunlar (DPK Notları). Erişim adresi: http://wfp14.org/wp-content/uploads/2020/06/Ceren-Uysal-O\%C4\%9Fuz_DPK_Not9.pdf

World Health Organization. (2020a). Coronavirus. Retrieved from https://www.who.int/healthtopics/coronavirus

World Health Organization. (2020b). WHO Coronavirus Disease (COVID-19) Dashboard. Retrieved from https://covid19.who.int/?gclid

World Population Review. (2020a). Mexico City Population. Retrieved from https://worldpopulationreview.com/world-cities/mexico-city-population

World Population Review. (2020b). Sao Paulo Population. Retrieved from https://worldpopulationreview.com/world-cities/sao-paulo-population

Worldometer. (2020). Coronavirus Brazil. Retrieved from https://www.worldometers.info/coronavirus/country/brazil/

Zanbak, M. (2019). Latin Amerika'nın seçilmiş ülkelerinde gelir dağılımı. C. Uysal Oğuz, S. Atvur, R. İzol (Ed.), 21. Yüzyllda Latin Amerika: Siyaset, Ekonomi, Toplum içinde (s. 253-270). Ankara: Seçkin. 


\title{
SOCIOECONOMIC IMPACTS OF COVID-19 PANDEMIC IN LATIN AMERICA: CASES OF BRAZIL AND MEXICO
}

\author{
EXTENDED SUMMARY
}

\section{Research Problem}

The Covid-19 outbreak that first appeared in China in December 2019, has swiftly affected the whole world, spreading to different regions within a couple of months. The first case in Latin America was reported in Brazil at the end of February 2020. After that, the rapid increase of cases in Latin America made the region the new hotspot of the Covid-19 pandemic at the end of May 2020. The effects of the Covid-19 outbreak in Latin America have been very grave. Many Latin American countries have been unable to contain the rapid increase of cases. The economic, social and political impacts as well as a high number of cases and death rates in the region proved that Latin America is one of the most affected regions in the world. Hence, this study aims to examine the socioeconomic effects of the pandemic in Brazil, which has the highest number of cases and deaths in the region, and Mexico, which has the highest mortality rate as of September 15,2020. Brazil had more than 4 million confirmed cases and more than 130 thousand deaths on the aforementioned date. With these numbers the country ranked second in the world after the USA at the time of writing. In Mexico, nearly 700 thousand cases were reported, and more than 70 thousand people have lost their lives because of the Covid-19. Although these figures may have changed in the period after the completion of the study, it would not be incorrect to comment that the numbers of cases and deaths continue to increase in both countries as the preventive measures prove to be insufficient.

\section{Methodology}

By analyzing the quantitative data collected from several sources such as Ministries of Health of related countries, the study claims that the highest confirmed case and mortality rate numbers between March 1, 2020 and September 15, 2020 demonstrate the severity of the situation in Latin America. The confirmed cases and mortality numbers of Brazil and Mexico are reflected in graphics and the density of the cases by region in both countries were depicted in respective maps. With comprehensive literature review in English, Turkish and Spanish, the study incorporates the historical perspective and the current developments in Latin America.

\section{Results and Conclusion}

The populist right Jair Bolsonaro government of Brazil and the populist left Andrés Manuel López Obrador government of Mexico have used similar discourses to downplay the pandemic since its outbreak and carried out similar unsuccessful policies regarding public health. Consequently, the assessment of various data revealed that Brazil and Mexico, as more developed economies of the region, have been experiencing difficulties in coping with the pandemic and they have been negatively affected in terms of socioeconomic conditions. It is also noticeable that the populist discourse and the insufficient policies of both Bolsonaro and López Obrador governments aggravated the situation and deepened the racial and economic 
inequalities in these countries. Therefore, this study also claims that there should be critical discussions about the populist governments in the region. Since the pandemic is still ongoing, there might have been changes in the data after the study was completed. However, the negative impacts of the pandemic throughout Latin America continued to be extremely serious. Therefore, this study also aims to establish a starting point for additional researches to be carried out on similar issues in the future. Finally, it could be foreseen that the political, social and economic implications of the pandemic in the Latin America region, and particularly Brazil and Mexico could be even more serious if the policies remain to be inefficient. 